\title{
The Impact of Structural Empowerment on Job Satisfaction: An Empirical Study in Mexico
}

\author{
Adriana Segovia Romo \\ Universidad Autónoma de Nuevo León \\ Rosalba Treviño Reyes \\ Universidad Autónoma de Nuevo León \\ Joel Mendoza Gomez \\ Universidad Autónoma de Nuevo León
}

\begin{abstract}
A major problem that has arisen in organizations of any kind is often related to job satisfaction. The objective of this empirical study is to determine the impact of structural empowerment on job satisfaction through psychological empowerment in middle-higher education teachers. Data were collected through a measurement instrument with previously validated items to a sample of 167 elements and were analyzed using structural equations. The hypothesis formulated is accepted. It is emphasized that the mediating effect of psychological empowerment impacts on job satisfaction in the proposed relationship.
\end{abstract}

Keywords: structural empowerment, psychological empowerment, work satisfaction

\section{INTRODUCTION}

Some rankings show that Mexico has one of the highest rates of job satisfaction in Latin America. Regardless, the study of human capital is increasingly of interest, investigating the attitudes and behaviors of employees to address potential problems and thereby avoid costs or staff turnover. This study analyses the impact of structural empowerment on job satisfaction by examining the effects of psychological empowerment on teachers in Mexico via structural analysis. As hypothesized, the results support a significant relationship between structural empowerment and increased job satisfaction through psychological empowerment.

\section{BACKGROUND}

The disruptive changes associated with globalization, open economies, and the development of new technologies have caused society to undergo a very rapid evolution, which is reflected in multiple contexts. Among such changes, it is now common to see four generations interacting in the same spaces and work environment within a single company. Individuals from each of these generations demand different and, from the point of view of other generations, odd requirements, in the workplace as a result 
of the lifestyles and values formed by their experiences. In the case of young people, they are more likely to require challenging proposals, personal and work growth, and work-life balance (Herrera, 2018).

With these changes and generational shifts, the study of human capital, allowing organizations to understand their employees' interpersonal relationships, has become ever-more important. A deeper understanding of the workforce allows management to make decisions that lead to increased efficiency and effectiveness across a company. When studying organizational behavior, it is very common to encounter problems about the workforce, which in many cases hinders the productivity and efficient performance of the organization. Currently, job satisfaction is one of the main problems that organizational research has focused on, and one of the areas of organizational behavior that has taken on the most importance (Chiang, Gomez and Salazar, 2014).

Job satisfaction is one of the most fruitful and controversial constructs in organizational psychology (Salessi and Omar, 2017). Job satisfaction has been defined as a positive and pleasurable emotional state resulting from the individual's personal assessment of their work and the experience gained in it, when considering their obligations, their supervisor and the organization itself (Locke, 1976; Sarwar and Khalid, 2011). Conceptions of job satisfaction have varied from a positive feeling a subject experiences when performing work that interests them to a measurable judgment about their own work (Salessi and Omar, 2016). Judge and Kammeyer-Mueller (2012) conceptualize it as an attitude, a set of cognitive and affective responses to the employment situation with important implications in employee behavior. Carayon, Smith and Haims (1999, quoted in Guerra, Santander and Rodriguez, 2017) mention that the importance of job satisfaction is reflected in society itself, that is, when employees are happy with their work, they improve their lives outside of the work environment, at home and in the social environment, with a more positive attitude towards life.

Five years ago, a Randstad study indicated that $80 \%$ of workers in Mexico said they are satisfied with their work, their position and their employer - a high percentage compared to other countries, such as Japan, where just $40 \%$ of workers said they were satisfied in their workplaces. The same study also emphasized that job satisfaction is one of the main drivers of productivity and efficiency at work, increasing the profitability of companies (La Jornada, 2014). More recently, Forbes (2018) indicated that Mexico is one of the countries with the highest job satisfaction in Latin America. That study considered aspects like overall employee satisfaction, remuneration and benefits, career opportunities, company culture and quality of life.

The demographic characteristics of employees may be related to their level of job satisfaction. According to Randstad Workmonitor, younger employees tend to have a higher level of job satisfaction; indeed, the rate of job satisfaction among workers under the age of 25 has increased continuously since 2015 (Betisweb, 2016). In addition, the $81 \%$ of the employees with higher education have the highest degree of job satisfaction (The Economist, 2016).

Like job satisfaction, empowerment is a well-established term, one adopted more than three decades ago in the labour context as comprising two aspects: structural and psychological empowerment (De los Ríos and Blanco, 2012). Structural empowerment is defined as a set of activities and practices carried out by management that give power, control and authority to their subordinates, giving them access to information, resources, support and opportunities to learn and develop (Chen and Chen, 2008; Cheng and Boey, 2015; Kanter, 1993, quoted in Teixeira, Nogueira and Alves, 2016).

Psychological empowerment has been defined as the increase in intrinsic motivation in the performance of the function, based on four concepts: meaning of the task, competence, self-determination and impact (Thomas and Velthouse, 1990), which guide the approach of the individual towards the performance of his function. It should be stressed that psychological empowerment is not a characteristic of personality; rather, it is a defined set of cognitions based on a certain context of work (Spreitzer, 1995, quoted in Orgambídez-Ramos, Moura and Almeida, 2017). 


\section{APPROACHING THE PROBLEM}

Structural empowerment has been considered to have an impact on job satisfaction, although many employees are more focused on other types of intrinsic motivation that are currently associated with the term psychological empowerment (Chang et al., 2010; Rico-Pico et al., 2016 and Seibert, Wang and Courtright, 2011). Although studies have been conducted focusing on employees of high-value companies and welfare services, the effects of structural empowerment on the job satisfaction of teachers in Mexico has not yet been examined. The proposed model for the present work is shown in Figure 1.

\section{Research Question}

What is the impact of structural empowerment (through its effect on psychological empowerment) on the job satisfaction on teachers of public middle-higher education institutions?

Middle-Higher education in Mexico is from 15 to 17 years old, high school level.

\section{Overall Goal}

To determine the impact of structural empowerment on job satisfaction through psychological empowerment in teachers of public institutions of middle-higher education in the citrus region of the state of Nuevo León, Mexico.

\section{Hypothesis}

H1: Structural empowerment positively impacts the job satisfaction of teachers of public middle-higher education institutions, an effect mediated by psychological empowerment.

\section{FIGURE 1}

\section{GRAPHICAL REPRESENTATION OF PROPOSED MODEL}

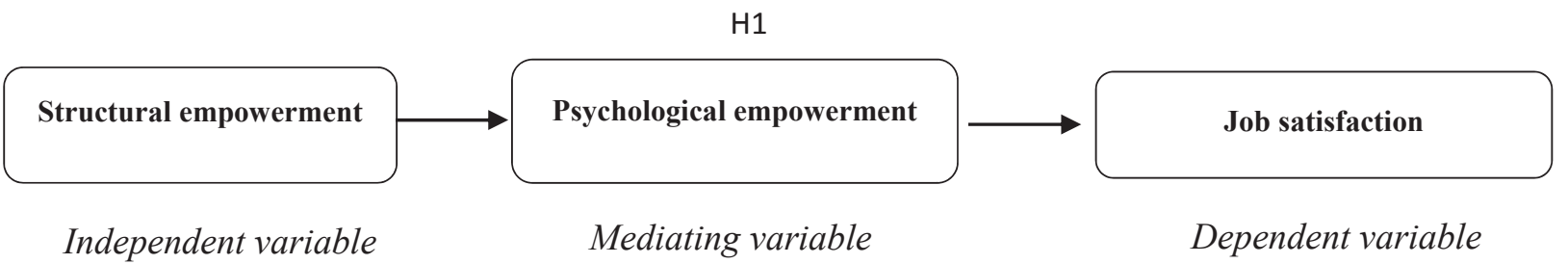

Source: Own elaboration

The study was carried out in the citrus region of Nuevo León state, Mexico. This geographical area has undergone important economic, organizational, commercial, educational and cultural development in recent decades. Outside the metropolitan area of Monterrey; it covers the municipalities of Linares, Hualahuises, Montemorelos, Allende, General Terán and Rayones (HCNL, 2017). The study was carried out from an administrative perspective oriented to the management of human capital, focusing on teachers of the higher middle level. This is a little-studied population (Barraza, 2008), and it is important to identify the degree of satisfaction of these teachers, as well as seek strategies to help increase their job satisfaction.

This work will be useful to educational institutions in designing strategies to retain teachers and keep them satisfied and motivated, influencing their efficiency, competitiveness and job performance, performing from non-monetary motivations. By extension, these improvements in teacher satisfaction should also promote an increase in student performance and graduation rates and a decrease in the rates of student dismissed. 


\section{METHODOLOGY}

The study was conducted with a quantitative approach, correlational, explanatory, non-experimental, transverse or cross-sectional design. According to data from the Ministry of Tourism (SECTUR, 2017) there are 15,206 teachers from higher middle-level public institutions in the State of Nuevo León, which is the general universe; 296 of them are located in the citrus region, making up the subject study population (UANL, 2018). To obtain sufficient statistical power, it was calculated (Gabaldon, 1980) that a sample size of 167 teachers was required, which were randomly chosen from the selected population maintaining the proportion for each of the 13 educational institutions in the study (Table 1).

\section{TABLE 1 \\ SAMPLE FRAMEWORK AND PROPORTION OF TEACHERS BY EDUCATIONAL INSTITUTION TO BE SURVEYED}

\begin{tabular}{lcc}
\hline Middle-Higher Education Institution & $\begin{array}{c}\text { Number of } \\
\text { teachers }\end{array}$ & Sample ratio \\
\hline CBTA No. 29 Linares & 22 & 12 \\
CECyTE Allende & 15 & 09 \\
CECyTE Hualahuises & 09 & 05 \\
CECyTE Linares & 32 & 18 \\
CECyTE Rayones & 06 & 03 \\
CETIS No. 163 José María Morelos y Pavón (Montemorelos) & 32 & 18 \\
CONALEP José María Parás y Ballesteros (Allende) & 20 & 12 \\
CONALEP Don Protasio Rodríguez Cuellar (Linares) & 38 & 22 \\
Escuela Industrial y Preparatoria Técnica Álvaro Obregón Unidad & 22 & 12 \\
Linares UANL & & \\
Preparatoria No. 4, UANL (Linares) & 35 & 20 \\
Preparatoria No 6, UANL (Montemorelos) & 20 & 11 \\
Preparatoria No. 13, UANL (Allende) & 27 & 15 \\
Preparatoria No. 14, UANL (General Terán) & 18 & 10 \\
\hline Total: & 296 & 167 \\
\hline
\end{tabular}

Source: Own elaboration by personal communication of the different institutions (2018)

In order to test the proposed model and measure the variables to be studied, the measurement instrument was integrated based on previously validated item scales from other empirical research and adapted to the study context. The questions (items) for each of the variables were taken based on the following validated scales: The Conditions of Work Effectiveness Questionnaire (CWEQ-II) (Laschinger, 1996, cited in O'Brien, 2010), The Psychological Empowerment Scale (Spreitzer, 1995, cited in O'Brien, 2010) and the Job Satisfaction Questionnaire S20/23 by Meliá and Peiró (1998).

The content validity process of the instrument was carried out, where the degree of relevance of the items was evaluated with the participation of 10 human capital experts. With the results obtained from this test, experts recommended restructuring (from a word, phrase or complete statement) and/or eliminating (integrating it to another item or suppressing it completely) several items, reflecting the modifications in the final measurement instrument integrated by items with a 7-point Likert scale.

The procedure for data collection consisted of going to each of the high schools in person, obtaining the authorization of the principals or staff in charge, addressing the teachers to explain the objective of the research and what the instrument is related to, as well as its application with the teachers who were available at the time or agreed to respond to the survey, considering the proportional amount of items per school to comply with the sample size.

When teachers required more time to complete the survey due to work issues, the questionnaires were left. In the next day or days, depending on their activities, they were collected. Data collection through 
visits to all the educational institutions analyzed was carried out in the period from March 12 to May 3, 2018.

Based on the type of research proposed in this study, a statistical analysis was performed with the Structural Equation Modeling (SEM) using the SmartPLS 3.0 M3 (Hair, Hult, Ringle and Sarstedt, 2017), since it allows to measure relationships between latent variables and to analyze several dependency relationships simultaneously.

\section{RESULTS}

A sample of 167 teachers responded to the questionnaire. The results are presented considering the responses of the Likert scale items and checking the reliability of the instrument through the Cronbach's alpha, meeting this criterion in each of the variables, this being greater than 0.70 .

The results of the composite reliability index of each variable are within the parameters considered acceptable (Table 2); although the values are greater than 0.90, they do not exceed 0.95 (Hair, et to., 2017). This index is considered a better approximation than Cronbach's alpha, as it assumes that the parameters are accurate and applies only when the latent variable has reflective indicators (Chin, 1998). According to Hair et al. (2017), the average extracted variance (AVE) is a reliability indicator for which a value of 0.50 or greater indicates a sufficient degree of convergent validity, meaning that, on average, the latent variable explains more than half of the variance of its indicators; the AVE for all variables exceeds 0.50 (Table 2).

TABLE 2

ITEM MODEL MEASUREMENT ANALYSIS RESULTS: RELIABILITY

\begin{tabular}{lccc}
\hline \multicolumn{1}{c}{ Variable } & $\begin{array}{c}\text { Cronbach's } \\
\text { alpha }\end{array}$ & $\begin{array}{c}\text { Composite } \\
\text { reliability }\end{array}$ & $\begin{array}{c}\text { Average extracted variance } \\
\text { (AVE) }\end{array}$ \\
\hline Structural empowerment & 0.934 & 0.944 & 0.629 \\
Psychological empowerment & 0.913 & 0.931 & 0.660 \\
Job Satisfaction & 0.908 & 0.926 & 0.610 \\
\hline
\end{tabular}

The structural model specifies the relationships between unobserved or latent variables. The trajectories or betas of the relationships and the value of $\mathrm{R}^{2}$ are estimated, and represent the degree of explanation of the independent variables on the dependent variable. The closer the $\mathrm{R}^{2}$ value is to 1 , the greater the variance explained by the model. $\mathrm{R}^{2}$ values of 0.668 and 0.892 are within the parameters considered as acceptable (Table 3) (Lopez, 2012).

\section{TABLE 3 \\ $R^{2}$ RESULTS FOR PARAMETERS}

\begin{tabular}{ll}
\hline Variable & $\mathrm{R}^{2}$ \\
\hline Psychological empowerment & 0.668 \\
Job satisfaction & 0.892 \\
\hline
\end{tabular}

Source: Own elaboration

Cohen's $\mathrm{f}^{2}$, the effect size, was calculated by considering the $\mathrm{R}^{2}$ values of the endogenous construct in the original model and in a model omitting the exogenous construct (Hair et al., 2017). Table 4 shows the $\mathrm{f}^{2}$ values obtained for model relationships, with values close to 0.02 considered low; close to 0.15 , mean; and close to 0.35 , large. 


\section{TABLE 4
MEASURING EFFECTS (COHEN'S $\mathrm{f}^{2}$ )}

\begin{tabular}{lc}
\hline Variable & $\mathrm{f}^{2}$ \\
\hline $\mathrm{SE} \rightarrow \mathrm{PE}$ & 1.422 \\
$\mathrm{SE} \rightarrow \mathrm{JS}$ & 1.390 \\
$\mathrm{PE} \rightarrow \mathrm{JS}$ & 0.223 \\
\hline
\end{tabular}

Note: SE, structural empowerment; PE, psychological empowerment; JS, job satisfaction. Source: Own elaboration

Because SEM does not assume that the data are normally distributed, nonparametric bootstrapping analysis was applied. Five thousand replicas were generated to replace the base sample in order to obtain the standard error for the hypothesis test. This technique provides an estimate of the shape, extent and bias of the sample distribution and treats the replicas generated as observed samples of the population (Henseler et al., 2009). Table 5 details the results obtained for the variables.

TABLE 5

TESTING OF STRUCTURAL MODEL SIGNIFICANCE

\begin{tabular}{lcccc}
\hline \multicolumn{1}{c}{ Path } & $\beta$ & Student's $t$ & $p$ & $\begin{array}{c}\text { Significant? } \\
(\mathrm{p}<0.05)\end{array}$ \\
\hline $\mathrm{SE} \rightarrow \mathrm{PE}$ & 0.764 & 18.780 & $p<0.001$ & Yes \\
$\mathrm{SE} \rightarrow \mathrm{JS}$ & 0.671 & 12.202 & $p<0.001$ & Yes \\
$\mathrm{PE} \rightarrow \mathrm{JS}$ & 0.270 & 4.387 & $p<0.001$ & Yes \\
\hline
\end{tabular}

Note: SE, structural empowerment; PE, psychological empowerment; JS, job satisfaction.

Source: Own elaboration

Mediation occurs when a third variable intervenes between two related constructs. A change in the exogenous construct results in a change in the mediating variable, to produce a change in the endogenous construct in a partial least squares (PLS) path model (Hair et al., 2017). The mediating effect of the psychological empowerment variable between the relationships of the exogenous and endogenous latent variable of the model is then evaluated. The effects of mediation are classified into direct and indirect. Direct effects are relationships that link two constructs by means of a connector, while indirect effects are relationships that involve a sequence of relationships with at least one construct intervening. The significance of these effects are presented in Table 6.

TABLE 6

ANALYSIS OF SIGNIFICANCE OF DIRECT AND INDIRECT EFFECTS

\begin{tabular}{lcccccccc}
\hline $\begin{array}{c}\text { Relationship } \\
\text { between } \\
\text { variables }\end{array}$ & $\begin{array}{c}\text { Direct } \\
\text { effect }\end{array}$ & $\begin{array}{c}\text { Student's } \\
t\end{array}$ & $p$ & $\begin{array}{c}\text { Significant? } \\
(\mathrm{p}<0.05)\end{array}$ & $\begin{array}{c}\text { Indirect } \\
\text { effect } \\
\text { (with } \\
\text { EP) }\end{array}$ & $\begin{array}{c}\text { Student's } \\
t\end{array}$ & $p$ & $\begin{array}{c}\text { Significant? } \\
(\mathrm{p}<0.05)\end{array}$ \\
\hline SE $\rightarrow$ JS & 0.671 & 12.202 & 0.000 & Yes & 0.206 & 4.057 & 0.000 & Yes \\
\hline
\end{tabular}

Note: SE, structural empowerment; PE, psychological empowerment; JS, job satisfaction

Source: Own elaboration

The results in Table 6 show that psychological empowerment has a significant indirect effect on the relationship between structural empowerment and job satisfaction; this is a "partial mediation" (Hair et al., 2017); therefore, the proposed research hypothesis is accepted (Table 7). It should be noted that the direct effect between structural empowerment and job satisfaction is also significant (Table 5). 


\section{TESTING OF THE RESEARCH HYPOTHESIS}

\begin{tabular}{lll}
\hline Specific hypotheses & Effect & Hypothesis \\
\hline H1. Structural empowerment has a positive impact on job & Partial mediation & Accepted \\
satisfaction through psychological empowerment & & \\
\hline
\end{tabular}

Source: Own elaboration

\section{DISCUSSION AND CONCLUSIONS}

As noted, human resources management has become increasingly interested in the study of the organizational behavior of its workforce. Among its social contributions, this research sought to provide information that can be used in the design of proposals and actions to keep this group of human talent satisfied and productive, working for reasons beyond financial motivation (OECD, 2011). According to a review of the literature, existing knowledge gaps and methodological challenges, the research model used in this work was proposed for application to the population and selected area (Creswell, 2015).

The research hypothesis was accepted, as the results support the positive and significant relationship between structural empowerment and job satisfaction mediated by psychological empowerment. No theoretical or empirical research appears to have studied this model as such, so this work is a contribution to the gap in this field and population segment. However, some researchers have examined similar effects in other populations.

The results of this work are somewhat in agreement with the findings of O'Brien (2010), who investigated a sample of 233 nursing professionals working in haemodialysis units. That work used a multiple regression analysis to test a mediation model, finding a statistically significant positive correlation between structural empowerment and psychological empowerment. Similar results have also been found by Corsun and Enz (1999), Ergenli, Ari and Metin (2007), Jáimez and Díaz (2011), Laschinger et al. (2003), Peterson and Speer (2000) and Ríos et al. (2010) in organizations of various types, especially those in the service sector-that structural empowerment acts as a predictor of job satisfaction via a mediating factor of psychological empowerment.

The significant, positive relationship between psychological empowerment and job satisfaction is like the effect seen in a study by Rico-Pico et al. (2016), examining samples of different working groups: teachers, health workers and law enforcement agencies. Others have also found that job satisfaction depends on the significance of the job, need for development in the position and experiences of autonomy at work (Chang et al., 2010; Deci and Ryan, 1985; Hackman and Oldham, 1980; Pearson and Moomaw, 2005; Seibert, Wang and Courtright, 2011); and is determined by the interaction between staff and environmental characteristics (Acker, 2004; Carayon, Smith and Haims, 1999, cited in Guerra, Santander and Rodríguez, 2017, Judge and Kammeyer-Mueller, 2012; Salessi and Omar, 2016; Salessi and Omar, 2017; Soto-Rosales and González-Losada, 2018).

It should be noted that the direct relationship of structural empowerment with job satisfaction is proportional, that is, the more support, information, resources and development opportunities teachers have, the greater their satisfaction in the workplace. This is further supported when incorporating psychological empowerment in its mediating role.

Some limitations of this work should be highlighted. First, the design of the study is cross-sectional and transversal, making it impossible to conduct a chronological or longitudinal comparison. In addition, there may be sample bias introduced by difficulties in obtaining lists and schedules for and establishing communication with some of the total population of teachers.

It is important to consider each aspect of this work when designing future research. Based on the results of this study, it is recommended to continue the inquiry, seeking more detail about other factors that could affect job satisfaction through psychological empowerment. Such research could be fruitful in both this context and in other educational institutions. It is also suggested to analyze the model developed here under a dimension scheme per construct in order to garner empirical findings relevant to 
organizations of any kind, due to the influence that these variables currently have on the behavior and attitudes of employees.

It is also suggested to analyze the model under a scheme of dimensions per construct in order to find empirical findings relevant to organizations. Dimensions by construct or variable refers to the fact that some variables such as Psychological Empowerment are made up of dimensions: meaning of the task, competence, self-determination and impact, and other studies have analyzed them not by complete construct or variable or as a whole, but by each one of their dimensions.

\section{REFERENCES}

Acker, J. (2004). The effect of organizational conditions (role conflict, role ambiguity, opportunities for professional development, and social support) on job satisfaction and intention to leave among social workers in mental health care. Community Mental Health Journal, 40(1), 65-73. DOI: https://doi.org/10.1023/B:COMH.0000015218.12111.26.

Barraza, A. (2008). Compromiso organizacional docente. Un estudio exploratorio. Avances en Supervisión Educativa, 8. Asociación de Inspectores de Educación en España.

Betisweb. (2016). Los menores de 25 años que tienen empleo son los más satisfechos con su trabajo. Retrieved from http://www.betisweb.com/otros-temas/179468-los-menores-de-25-anos-quetienen-empleo-son-los-mas-satisfechos-con-su-trabajo.html\#ixzz4PefeWv00.

Chang, L., Shih, C., \& Lin, S. (2010). The mediating role of psychological empowerment on job satisfaction and organizational commitment for school health nurses: A cross-sectional questionnaire survey. International Journal of Nursing Studies, 47(4), 427-433. Retrieved from https://www.sciencedirect.com/science/article/pii/S0020748909003149. https://doi.org/10.1016/j.ijnurstu.2009.09.007.

Chen, H., \& Chen, Y. (2008). The impact of Work Redesign and Psychological Empowerment on Organizational Commitment in a Changing Environment: An Example From Taiwan's StateOwned Enterprises. Public Personnel Management, 37, 279-302.

Cheng, Y. L. T., \& Boey, K. W. (2015). Structural Empowerment among Frontline Nurses in Hong Kong: A Study on the Moderating and Mediating Effect of Self-Esteem. Ann Nurs Pract, 2(3), 1027.

Chiang, M. M., Gómez, N. M., \& Salazar, C. M. (2014). Satisfacción laboral y estilos de liderazgo en instituciones públicas y privadas de educación en Chile. Cuadernos de Administración (Universidad del Valle), 30(52), 65-74.

Chin, W. W. (1998). The partial least squares approach to structural equation modeling. In: G.A. Marcoulides (Ed.), Modern methods for business research (pp. 295-335). Mahwah, NJ:Erlbaum.

Corsun, D., \& Enz, C. (1999). Predicting psychological empowerment among service workers: the effect of support-based relationships. Human Relations, 53(2), 205- 224.

Creswell, J. W. (2015). Research Design: Qualitative, quantitative, and mixed method approaches. 4th. Edition. Thousand Oaks: Sage Publications.

Ergenli, A., Ari, G., \& Metin, S. (2007). Psychological empowerment and its relationship to trust in immediate managers. Journal of Business Research, 60, 41-49.

De los Ríos, P., \& Blanco, M. M. (2012). El empowerment organizacional: revisión de modelos teóricos y su aplicabilidad en la gestión empresarial. Universidad de Almería.

Deci, E. L., \& Ryan, R. M. (1985). Intrinsic motivation and self-determination in human behavior. New York: Springer.

El Economista. (2016). Tres de cada cuatro trabajadores están satisfechos con su empleo, según randstad. Retrieved from http://www.eleconomista.es/economia/noticias/7941648/11/16/Tres-de-cadacuatro-trabajadores-estan-satisfechos-con-su-empleo-segun-randstad.html.

Forbes. (2018). México, entre países con mayor satisfacción laboral de América Latina. Retrieved from: https://www.forbes.com.mx/mexico-entre-paises-con-mayor-satisfaccion-laboral-de-americalatina/. 
Gabaldon, N. (1980). Algunos conceptos de muestreo (3ra. Ed.). Caracas, Venezuela: Universidad Central de Venezuela, Facultad de Ciencias Económicas y Sociales, División de publicaciones.

Guerra, P., Santander, S., \& Rodríguez, P. (2017). Satisfacción laboral y su relación con el estrés. Revista CienciAmérica, 6(1), 27-33. Retrieved from

http://www.cienciamerica.us/openjournal/index.php/uti/article/view/68.

Hackman J.R., \& Oldham G.R. (1975) Motivation through the design of work: testing of a theory. Organizational Behavior and Human Performance, 11, 250-279.

Hair, J. F., Hult, G. T. M., Ringle, C. M., \& Sarstedt, M. (2017). A Primer on Partial Least Squares Structural Equation Modeling, 2nd Ed. Thousand Oaks: Sage.

HCNL. (2017). Ley de Fomento a la Inversión y al Empleo para el Estado de Nuevo León. Retrieved from

http://www.hcnl.gob.mx/trabajo_legislativo/leyes/leyes/ley_de_fomento_a_la_inversion_y_al_e mpleo_para_el_estado_de_nuevo_leon/.

Henseler, J., Ringle, C. M., \& Sinkovics, $\bar{R}$. R. (2009). The use of partial least squares path modeling in international marketing. Advances in International Marketing, 20, 277-319. Retrieved from https://ssrn.com/abstract=2176454.

Herrera, R. (2018). Satisfacción laboral como factor de permanencia de la generación millennial, para reducir la rotación en los centros de trabajo. Retrieved from https://escueladenegocios.edu.mx/el-educador/2018/05/08/satisfaccion-laboral-como-factor-depermanencia-de-la-generacion-millennial-para-reduccion-de-rotacion-de-personal/.

Judge, T. A., \& Kammeyer-Mueller, J. D. (2012). Job attitudes. Annual Review of Psychology, 63, 341 367. DOI: 10.1146/annurev-psych-120710-100511.

La Jornada. (2014). En México, 80\% de los trabajadores están satisfechos con su trabajo, según encuesta. Retrieved from http://www.jornada.unam.mx/2014/08/03/politica/017n1pol.

Laschinger, H., Finegan, J., Shamian, J., \& Wilk, P. (2003). Workplace empowerment as a predictor of nurse burnout in restructured healthcare settings. Longwoods Review, 1(3), 2-11.

Locke, E. A. (1976). The nature and causes of job satisfaction. Chicago: Dunnette. Handbook of Industrial and Organizational Psychology, Rand McNally, Chicago, IL, 1297-349.

López, J. F. (2012). Optimización Combinatoria y Modelos Multivariables Robustos. Alemania: vEditorial académica española.

Meliá, J. L., \& Peiró, J. M. (1998). Cuestionario de satisfacción laboral S20/23. Psicología de la seguridad. España: Universidad de Valencia.

O'Brien, J. L. (2010). Structural empowerment, psychological empowerment and burnout in registered staff nurses working in outpatient dialysis centers (Doctoral dissertation, Rutgers UniversityGraduate School-Newark).

OCDE. (2011). Establecimiento de un marco para la evaluación e incentivos docentes: Consideraciones para México. México: OECD Publishing.

Orgambídez-Ramos, A., Moura, D., \& Almeida, H. D. (2017). Estrés de rol y empowerment psicológico como antecedentes de la satisfacción laboral. Revista de Psicología (PUCP), 35(1), 257-278. DOI: http://dx.doi.org/10.18800/psico.201701.008.

Peterson, N. A., \& Speer, P. (2000). Linking organizational characteristics to psychological empowerment: Contextual issues in empowerment theory. Administration in Social Work, 24(4), 39-58.

Pearson, L. C., \& Moomaw, W. (2005). The relationship between teacher autonomy and stress, work satisfaction, empowerment, and professionalism. Educational Research Quartely, 29(1), 38-54.

Rico-Picó, J., Peinado-Estévez, Á., Salvador-Ruiz, M., y González-Fuentes, F. (2016). Empowerment, satisfacción laboral e identificación organizacional en funcionarios andaluces. ReiDoCrea, 5(2), 33-39. Retrieved from https://www.ugr.es/ reidocrea/5-2-6.pdf

Ríos, M., Rayo, M., \& Ferrer, J. (2010). El empowerment como predictor del compromiso organizacional en las Pymes. Contaduría y administración, 26(231), 103-125. 
Salessi, S., \& Omar, A. (2016). Satisfacción laboral genérica. Propiedades psicométricas de una escala para medirla. Revista Alternativas en Psicología, 34, 93-108. Retrieved from http://www.alternativas.me/attachments/article/116/8\%20\%20Satisfacci\%C3\%B3n\%20Laboral\%20Gen\%C3\%A9rica.pdf.

Salessi, S., \& Omar, A. (2017). Satisfacción laboral: un modelo explicativo basado en variables disposicionales. Revista Colombiana de Psicología, 26(2), 329-345. DOI: http://dx.doi.org/10.15446/rcp.v26n2.60651.

Sarwar, A., \& Khalid, A. (2011). Impact of employee empowerment on employee's job satisfaction and commitment with the organization. Interdisciplinary Journal of Contemporary Research in Business, 3(2), 664.

SECTUR. (2017). Anuario estadístico y geográfico de Nuevo León 2017. Retrieved from http://www.datatur.sectur.gob.mx/ITxEF_Docs/NL_ANUARIO_PDF.pdf.

Seibert, S. E., Wang, G., \& Courtright, S. H. (2011). Antecedents and consequences or psychological and team empowerment in organizations: A meta-analytic review. Journal of Applied Psychology, 96(5), 981-1003. Retrieved from https://www.researchgate.net/publication/50890449_Antecedents_and_Consequences_of_Psycho logical_and_Team_Empowerment_in_Organizations_A_Meta-Analytic_Review.

Soto-Rosales, A., \& González-Losada, S. (2018). Satisfacción laboral y desgaste profesional en trabajadores de servicios sociales de atención a la infancia. Trabajo Social Global - Global Social Work, 8(14), 80-107. DOI: 10.30827/tsg-gsw.v8i14.7222.

Teixeira, A. C., Nogueira, M. A. A., \& Alves, P. J. P. (2016). Structural empowerment in nursing: translation, adaptation and validation of the Conditions of Work Effectiveness Questionnaire II/Empoderamento estrutural em enfermagem: tradução, adaptação e validação do Conditions of Work Effectiveness Questionnaire II/Empoderamiento estructural en enfermería: traducción, adaptación y validación del Conditions of Work Effectiveness Questionnaire II. Revista de Enfermagem Referência, 4(10), 39. DOI:10.12707/RIV16014.

Thomas, K., \& Velthouse, B. (1990). Cognitive Elements of Empowerment: An "Interpretive" Model of Intrinsic Task Motivation. Academy of Management Review, 15, 666-681. Retrieved from https://www.jstor.org/stable/258687?seq=1\#page_scan_tab_contents. DOI: 10.2307/258687.

UANL. (2018). Directorio de planteles de nivel medio superior (Nuevo León). Proceso de Asignación de Espacios en la Educación Media Superior del Estado de Nuevo León 2018. Retrieved from $\mathrm{http}$ ://www.uanl.mx/alumnos/convocatorias/registro-de-aspirantes-preparatoria-en-modalidadpresencial.html. 